\title{
Assessment of the exposure to organochlorine pesticides, PCBs and PAHs in six species of predatory birds of the Canary Islands, Spain
}

\author{
Octavio P. Luzardo *, Norberto Ruiz-Suárez, Luis Alberto Henríquez-Hernández, Pilar F. Valerón, \\ María Camacho, Manuel Zumbado, Luis D. Boada
}

Toxicology Unit, Department of Clinical Sciences, University of Las Palmas de Gran Canaria, Plaza Dr. Pasteur s/n, 35016 Las Palmas de Gran Canaria, Spain

\section{H I G H L I G H T S}

- Monitoring of 57 POPs in six species of birds of prey

- High levels of DDTs and dieldrin consistent with previous reports of this area

- Non hazardous-low levels of PCBs found in these animals

- First report on polycyclic aromatic hydrocarbons in these species

- Levels of PAHs below the values considered as toxic in predictive models

\section{G R A P H I C A L A B S T R A C T}
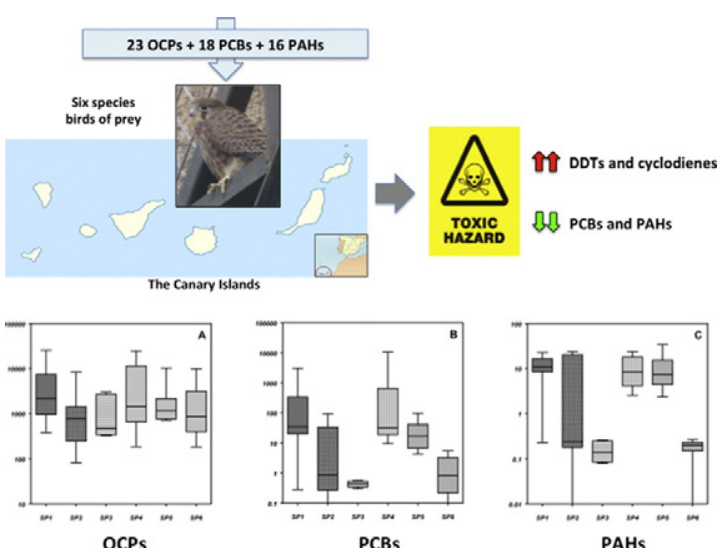

\begin{abstract}
A B S T R A C T
In the present study, we investigated the concentrations and distributions of 57 anthropogenic pollutants, including 23 organochlorine pesticides (OCs), 18 polychlorinated biphenyls (PCBs) and 16 polycyclic aromatic hydrocarbons (PAHs) in liver samples from 102 birds of prey of six species that were found dead or that had died during their stay in the Wildlife Recovery Centers of the Canary Islands (Spain) between 2009 and 2012. The dual goal of this work was to determine the occurrence of these contaminants in these six species of birds of prey, and also whether they can be used as bioindicators for monitoring environmental pollution in the region. We found that Accipiter nisus, Falco pelegrinoides and Falco tinnunculus were the most contaminated species. The profiles of contamination among the species were extremely similar in the case of organochlorine contaminants, with DDT and its metabolites as the most abundant compounds. The contamination by DDT and its metabolites, as well as contamination by dieldrin, could be considered high in these animals, much higher than reports from other regions of the planet, which is in agreement with previous reports from our group regarding humans, food and other animals from this area. In contrast, the contamination by PCBs could be considered extremely low and was probably below the threshold of toxicity for these contaminants. The content of carcinogenic/mutagenic PAHs in these animals was clearly dependent on the feeding pattern of the species; however, the levels were also well below the values that were considered toxic in predictive models. This study represents the first report of contamination by PAHs in all these species and is also the first report of PCB levels in Barbary Falcons.
\end{abstract}

(c) 2013 Elsevier B.V. All rights reserved.

\footnotetext{
* Corresponding author at: Toxicology Unit, Department of Clinical Sciences Health Sciences Faculty, University of Las Palmas de Gran Canaria, Plaza Dr. Pasteur s/n, 35016 Las Palmas de Gran Canaria, Spain. Tel.: +34 928453 472; fax: + 34928451416
}

E-mail address: operez@dcc.ulpgc.es (O.P. Luzardo). 


\section{Introduction}

Persistent organic pollutants (POPs) are toxic chemicals that are resistant to degradation in the environment and biota. Due to their fat solubility and resistance to chemical and biological degradation, ingestion of certain classes of POPs by animals leads to bioaccumulation throughout their lives, generally in the fatty tissues, and to biomagnification in the food chain (Gioia et al., 2013; Safe, 1994). Among the POPs, organochlorine pesticides (OCPs) and polychlorinated biphenyls (PCBs) are highly prevalent in vertebrates. Because of their efficient metabolization, strictly speaking, polycyclic aromatic hydrocarbons (PAHs) cannot be considered as POPs, but due to their high prevalence in the environment and their lipophilicity, PAHs are usually considered as POPs. The majority of POPs, such as PCBs and OCPs, are currently banned from use and are no longer produced or used around the world; therefore, their levels have been constantly declining through the years (Addison et al., 2013; Ryan et al., 2013; Schuster et al., 2011). Nevertheless, relevant amounts of these pollutants still persist in the environment, and certain species, especially those top predators, are especially contaminated (Bourgeon et al., 2013; Olafsdottir et al., 2001), and it has been described that these pollutants lead to adverse health effects on living beings (Hamlin and Guillette, 2010). Birds of prey are especially prone to POP accumulation due to their high position on the food chain and high rates of food consumption (Fernie and Letcher, 2010; Tillitt et al., 1992). Many adverse effects have been described in relation to birds' exposure to POPs, such as eggshell thinning, decreased reproductive success (Ratcliffe, 1967), reduced normal sexual behavior, smaller brain size, or neurotoxicity (Iwaniuk et al., 2006), among others.

The Canary Islands are located $1600 \mathrm{~km}$ away from southwest Spain, in the Atlantic Ocean, and 63 miles away from the nearest point on the North African coast (southwest of Morocco) (Fig. 1). Geographically, the Islands are part of the African continent; however, from historical, economic, political and sociocultural points of view, the Canaries are European. Notably, large quantities of organochlorine pesticides have been used in the past in this archipelago because of the important role of agriculture in the economy of the region (Diaz-Diaz and Loague, 2001). For this reason, the levels of POP contamination in the human population of the archipelago have been deeply studied. Thus, whereas this population shows lower levels of PCB contamination than many populations from developed countries (Henriquez-Hernandez et al., 2011), chronic exposure to DDT and its metabolites, as well as to some cyclodienes, seems to currently persist (Luzardo et al., 2006; Zumbado et al., 2005). These findings correlate with the presence of these pollutants in food items that are consumed in this region, particularly those food items that are locally produced (Almeida-Gonzalez et al., 2012;
Luzardo et al., 2012, 2013b). Moreover, potential adverse health effects of POPs have been described in marine wildlife in nearby areas (Camacho et al., 2012, 2013).

Due to the relative isolation of the archipelago and its climate, the flora and fauna in the islands are completely different from those of the European and African continents. Here, many endemic species and subspecies are found in areas of high ecological value. There are 7 species of diurnal birds of prey and 2 nocturnal nesting birds of prey in the Canary Islands. Four of these species are endemic to the Canary Islands, and two species are endemic to the Macaronesian region (which includes the Azores, Madeira, Canaries and Cape Verde) (Lorenzo et al., 2012). These raptors have suffered a population decline in recent decades and have several threats to their survival, including power lines, malicious or accidental poisonings, slow reproductive rates, high tourist pressure on the territory (the archipelago has four national parks that receive 5.5 million visitors a year (MAGRAMA, 2013)), as well as the extensive use of pesticides in the past and also currently, among others. In particular, pesticides, specifically organochlorines, can cause reproductive failure in birds and are responsible for the population decline of several birds of prey worldwide. Despite the potential risks to birds of prey, little exposure data for pesticides or pollutants exist for wild populations, particularly those populations utilizing terrestrial food webs (Yordy et al., 2013). To address this gap in the data, we have evaluated the concentrations of $57 \mathrm{POPs}$, including organochlorine pesticides (OCs), polychlorinated biphenyls ( $\mathrm{PCBs}$ ), and polycyclic aromatic hydrocarbons (PAHs), in liver samples of 102 birds of prey, which belong to six different species from the Canary Islands, and we have compared these levels with the thresholds of toxicity that have been established for these pollutants in order to elucidate if raptor species of the archipelago are exposed to toxic amounts of anthropogenic pollutants, which could represent a threat for their conservation. In addition, the accumulation patterns of these pollutants in the liver of these animals are utilized as additional "biological indicators" for assessing the current level of environmental contamination by POPs in this archipelago.

\section{Materials and methods}

\subsection{Sample collection and ethics statement}

Liver samples were obtained from necropsies of 102 birds of prey from 6 species that were admitted to the Wildlife Recovery Centers (WRCs) of Tafira (Gran Canaria, Spain) and La Tahonilla (Tenerife, Spain) between October 2009 and December 2012. Birds that were sampled included 12 Common Buzzards (Buteo buteo), 16 European Sparrowhawks (Accipiter

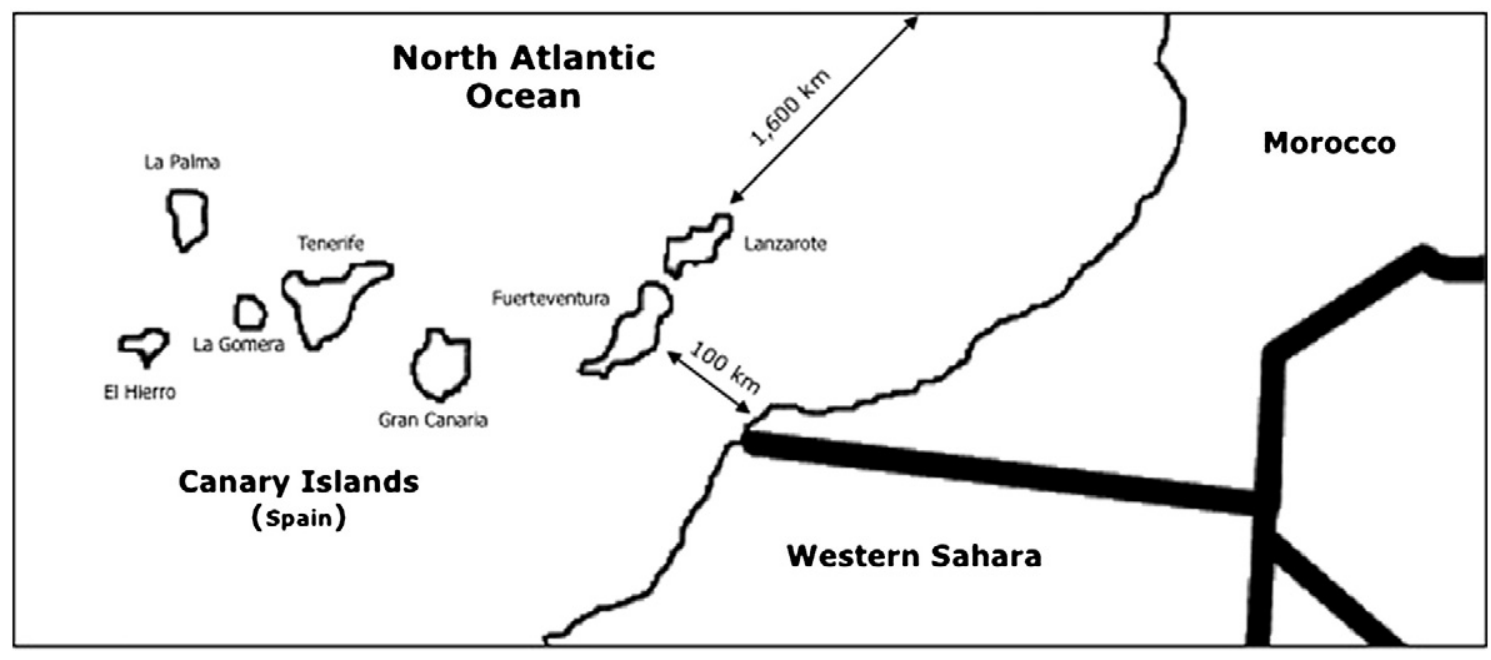

Fig. 1. Canary Islands archipelago in northwestern African coast (arrows: minimal distance from Spanish and Moroccan coasts). 
nisus), 20 Barbary Falcons (Falco pelegrinoides), 20 Common Kestrels (Falco tinnunculus), 14 Long-eared Owls (Asio otus), and 20 Barn Owls (Tyto alba). The birds died naturally or were euthanized within one week of admission, and necropsies were performed within $72 \mathrm{~h}$ postmortem. No animal was killed for the purposes of this study. The main cause of death was determined by examining the birds macroscopically in the WRCs, and, when necessary, radiological, histological, or toxicological analyses were performed. The causes of death for all the animals that were included in this study included different types of trauma. Livers were excised and stored at $-20{ }^{\circ} \mathrm{C}$ until sample preparation.

\subsection{Chemicals and reagents}

Dichlorometane, hexane, ethyl acetate and cyclohexane were of the highest purity available (>99.9\%) and were purchased from Fisher Scientific (Leicestershire, United Kingdom). Ultrapure (UP) water was produced from a Milli-Q Gradient A10 (Millipore, Molsheim, France). Diatomaceous earth was purchased from Sigma-Aldrich (St. Louis, USA). Bio-Beads SX-3 were purchased from BioRad Laboratories (Hercules, USA). Standards of OCPs, PCB congeners, surrogates (PCB 12, PCB 202, p, $p^{\prime}-$ DDE- $d_{8}$, acenaphtylene- $\mathrm{d}_{8}$ ) and internal standards (ISs, tetrachloro-m-xylene, trans-heptachlor epoxide, and benzo[a]pyrene$\mathrm{d}_{12}$ ) were purchased from Dr Ehrenstorfer (Augsburg, Germany). Standards of PAHs were purchased from Absolute Standards, Inc. (Connecticut, USA). All standards were pure compounds (purity from $97 \%$ to $99.5 \%$ ). Stock solutions of each compound at $1 \mathrm{mg} / \mathrm{mL}$ were prepared in cyclohexane and stored at $-20{ }^{\circ} \mathrm{C}$. Diluted solutions from $0.05 \mathrm{ng} / \mathrm{mL}$ to $100 \mathrm{ng} / \mathrm{mL}$ were used for calibration curves.

\subsection{Analytes of interest}

In total, 57 analytes, which belonged to three relevant groups of POPs, were selected for this study. The 23 OCPs and metabolites included the diphenyl-aliphatics (methoxychlor, $o, p^{\prime}$-DDT, $p, p^{\prime}$-DDT, $o, p^{\prime}$-DDE, $p, p^{\prime}$-DDE, o, $p^{\prime}$-DDD, $p, p^{\prime}$-DDD, and dicofol); the persistent and bioaccumulative contaminant hexachlorobenzene ( $\mathrm{HCB})$; the four isomers of hexachlorocyclohexane $(\alpha-, \beta-, \delta-$, and $\gamma-\mathrm{HCH})$; the cyclodienes heptachlor, dieldrin, aldrin and endrin, chlordane (cis- and transisomers) and mirex; and endosulfan ( $\alpha$ - and $\beta$-isomers) and endosulfan sulfate. With respect to the PCBs, we included 18 congeners: the dioxin-like congeners (DL-PCBs) (IUPAC numbers 77, 81, 105, 114, $118,123,126,156,157,167,169$ and 189), and the six marker congeners of non-dioxin-like PCBs (M-PCBs) (IUPAC numbers 28, 52, 101, 138,153 and 180). Finally, we also included in the suite of analytes that is on the list of the 16 EPA priority PAHs that are often targeted for measurement in environmental samples (naphthalene, acenaphtylene, acenaphtene, fluorene, phenanthrene, anthracene, fluoranthene, pyrene, benz[a]anthracene, benzo[b]fluoranthene, benzo[k]fluoranthene, benzo [a]pyrene, indeno[1,2,3-cd]pyrene, dibenz[a,h]anthracene and benzo [ghi]perylene).

\subsection{Sample preparation}

Because the contaminants included in this study are completely lipid-soluble and, therefore, are found in the lipid fraction of tissues, we first extracted the fat from the liver tissue. In total, $5 \mathrm{~g}$ of liver was finely chopped with scissors and homogenized in $5 \mathrm{~mL}$ ultrapure water with a disperser (Ultra-turrax, IKA, China). This homogenate was spiked with the $10 \mathrm{ppm}$-surrogate mix in acetone to a final concentration of $100 \mathrm{ppb}$ and was mixed with $30 \mathrm{~g}$ of diatomaceous earth to absorb moisture. The method of extraction and clean up followed the method that was previously recommended by the European Standard for the determination of pesticides and PCBs in fatty foods (EN European Norm, 1528-2, 1996, EN European Norm, 1528-3, 1996) and whose validity has been previously proven in our laboratory for different fatty samples (Almeida-Gonzalez et al., 2012; Luzardo et al., 2012, 2013a). This method combines an automated Soxhlet extraction method (FOSS Soxtec Avanti 2055) with a purification step using gel permeation chromatography (GPC) and gives acceptable recoveries that ranged between $74.5 \%$ and $104.7 \%$. Additional clean-up steps were not required, and the $1 \mathrm{~mL}$-extracts in cyclohexane that were obtained at the end of the GPC were used for the chromatographic analysis.

\subsection{Procedure of chemical analysis}

Gas chromatography analyses of 57 contaminants, 4 surrogates and 3 ISs were performed in a single run on a Thermo Trace GC Ultra, which was equipped with a TriPlus Autosampler and coupled to a Triple Quadrupole Mass Spectrometer Quantum XLS (Thermo Fisher Scientific Inc., Waltham, MA, USA), using appropriate internal standards (ISs) as previously described and validated in our laboratory (Camacho et al., 2012, 2013; Luzardo et al., 2013c). A fused silica capillary column BPX5 (crosslinked 5\% phenyl methylpolysiloxane, SGE Inc., USA) with a length of $30 \mathrm{~m}$, a $0.25 \mathrm{~mm}$ i.d. and a film thickness of $0.25 \mu \mathrm{m}$ was used as the stationary phase. Helium (99.999\%) at a constant flow rate of $1.0 \mathrm{~mL} / \mathrm{min}$ was used as the carrier gas. The temperatures were programmed as follows: the initial oven temperature of $60{ }^{\circ} \mathrm{C}$ was maintained for $1 \mathrm{~min}$, ramped at $12{ }^{\circ} \mathrm{C} / \mathrm{min}$ to $210{ }^{\circ} \mathrm{C}$, then raised at $8{ }^{\circ} \mathrm{C} / \mathrm{min}$ to $320^{\circ} \mathrm{C}$ with a 6 min hold time. The total run time was $61 \mathrm{~min}$. The injector and transfer line were set to $270{ }^{\circ} \mathrm{C}$ and $310{ }^{\circ} \mathrm{C}$, respectively. The standards and samples were injected $(1 \mu \mathrm{L})$ in the splitless mode. Thermo Fisher Xcalibur software (Ver. 2.0.1) was used for the instrument control, data acquisition, and data analysis. After the retention times were determined in full scan mode (range $\mathrm{m} / \mathrm{z} 45-650$ ), a timed selected reaction monitoring (SRM) method was developed to analyze the 57 target compounds plus four surrogates and three internal standards in one single run. A calibration curve was constructed from 0.05 to $100 \mathrm{ng} / \mathrm{mL}$ with all the compounds, with the exception of the surrogates and internal standards, contained in each calibration standard mixture. Argon (99.99\%) was used as the collision gas, and the collision cell pressure was set to $0.2 \mathrm{~Pa}$. The triple quadrupole mass spectrometer was operated under the following conditions: ionization with electron impact at $70 \mathrm{eV}$ in MRM with an emission current of $50 \mu \mathrm{A}$. The ionization source temperature was set to $220^{\circ} \mathrm{C}$. A filament multiplier delay of 5 min was established to prevent instrument damage. The electron multiplier voltage was set to $1500 \mathrm{~V}$. The scan width was 0.15 , and the scan time was $0.05 \mathrm{~s}$. Peak widths of $\mathrm{m} / \mathrm{z} 0.7$ Da were set for both the first (Q1) and third quadrupole (Q3). The analytical performance of this method (confirmation criteria, precision, linearity, limits of quantification (LOQs), and repeatability) has been previously studied and published (Luzardo et al., 2013c). We added $20 \mu \mathrm{L}$ of the IS mixture, which was prepared at $1 \mathrm{ppm}$ in cyclohexane, immediately before the GC-MS/MS analysis. Because no matrix effects have been observed with this method, all quantifications were performed against a 10-point calibration curve using cyclohexane ( 0.05 to $\left.40 \mu \mathrm{g} \mathrm{L}^{-1}\right)$.

\subsection{Quality control}

The recoveries of the 57 analytes and surrogates were acceptable with this method because the recoveries were invariably above $74 \%$. All the individual measurements were corrected by the recovery efficiency for each analyte. All the measurements were performed in triplicate, and the values used for calculations were the mean of the three measurements. In each batch of samples, two controls were included with every 12 samples. For the chromatographic procedure we used a reagent blank, which consisted of a vial containing only cyclohexane that was spiked with the surrogates and ISs. Besides an internal laboratory quality control of the whole procedure was included (QC), which consisted of melted butter that was spiked at $20 \mathrm{ng} / \mathrm{g}$ for each of the analytes that was processed with the same method as the samples. The batch analyses were considered valid when the values of the 
analytes in the QC and the reagent blank were within a 10\% deviation of the theoretical value.

\subsection{Statistical analyses}

The database management and statistical analyses were performed using the PASW Statistics v18.0 software (SPSS Inc., Chicago, IL, USA). Because the POP levels (individually or grouped) did not follow a normal distribution, the results were expressed with the median and the 5th and 95th percentiles of the distribution. Differences in POP concentrations among two groups or more were tested with the nonparametric Mann-Whitney U-test and the Kruskal-Wallis test. The categorical variables were presented as percentages and were compared between variables with the chi-square test. P values of less than 0.05 (two-tail) were considered statistically significant.

\section{Results and discussion}

\subsection{Accumulation pattern of OCPS}

Organochlorine pesticide residues were detected in all the samples of birds that were analyzed in this study (Table 1 ). A mean of 5 residues per sample was found (range 3 to 14). The presence of $\alpha-\mathrm{HCH}, \delta-\mathrm{HCH}$, heptachlor, aldrin, endrin, $\alpha$-endosulfan, $\beta$-endosulfan, and metoxichlor was not detected in any sample of liver. In contrast, 3 compounds were detected in $100 \%$ of samples: $p, p^{\prime}$-DDE, dieldrin, and $\beta-\mathrm{HCH}$. In recent studies from different regions of the world, other authors have reported a similar pattern of contamination, where $p, p^{\prime}$-DDE and $\mathrm{HCH}$ isomers were the chief contributors to the total OC content (Dhananjayan, 2013b; Gomez-Ramirez et al., 2012; Yordy et al., 2013). We observed a high dispersion in the level of residues among species (Fig. 2A). $A$. nisus, F. pelegrinoides and $F$. tinnunculus were the most contaminated species, with total OCP contents of 2160, 1419 and $1154 \mathrm{ng} / \mathrm{g}$ wet weight, respectively (Table 1). Notably, dicofol was present with high frequency in our set of samples and at concentrations ranging from 1.0 to $9.3 \mathrm{ng} / \mathrm{g}$ wet weight. This residue is not usually included in the set of analytes that is measured in environmental samples; therefore, we cannot compare our results with many previous studies. However, this pesticide has been found in wild bird eggs with similar frequency and concentrations (Malik et al., 2011). The high frequency presence of this residue might be explained by its thorough use in the cultivation of tropical fruits in the Canary Islands in the past, and also because this pesticide, which is an important source of DDT, was produced in Spain until late 2008.

In general, we found lower levels of contamination by OCPs in these birds from the Canaries than OCP levels in birds from other regions of the world. However, the high levels of DDTs and dieldrin that were found are two remarkable differences that should be highlighted. We found much higher levels of these pesticides (Table 1) than in prey birds from the USA (range from 1.8 to $3240.8 \mathrm{ng} / \mathrm{g}$ wet weight) (Yordy et al., 2013), mainland Spain (median $6248.19 \mathrm{ng} / \mathrm{g}$ lipid weight) (Gomez-Ramirez et al., 2012), Italy (range from 110.2 to $215.7 \mathrm{ng} / \mathrm{g}$ wet weight) (Licata et al., 2012), or even from India (range from 3.0 to $520.0 \mathrm{ng} / \mathrm{g}$ wet weight) (Dhananjayan, 2013b), where the use of DDT remains allowed for malaria control. However, these results are in agreement with our studies in human blood samples that were taken 15 years ago (Luzardo et al., 2006; Zumbado et al., 2005), and more recently, in amniotic fluid samples (Luzardo et al., 2009), or in some food items that were produced in this archipelago (AlmeidaGonzalez et al., 2012; Luzardo et al., 2012). The current level of contamination by DDTs and dieldrin is surprisingly high because in Spain, as well as all other developed countries, the usage of OCPs ceased in the late 1970 s or the beginning of the 1980s. These results could be explained, at least in part, by two facts: the extreme environmental persistence of these compounds and the proximity to the African continent. The first factor is most likely to be the major cause because many organochlorine pesticides have been used in this area in the past. There are no reliable data regarding the consumption of these products; however, until the political awareness of pesticide consumption in recent years, the pesticide consumption in the islands was as high as 12 times (>200 kg/Ha, 42\% insecticides) than that of the rest of the country (Diaz-Diaz and Loague, 2001; MAGRAMA, 2006). Several circumstances could explain this high use of pesticides, such as the weather conditions that favor the occurrence of pests and the fact that many farmers abuse pesticides by implementing scheduled preventative treatments, overdosing, and continue to ignore basic instructions regarding their use. Therefore, it is more than likely that this situation was similar or even worse in the past, when organochlorines were available as the only option. Alternatively, the high level of pollution that we have found can also be explained in part by the proximity of these islands to the African continent. Several prohibited OCs remain under use in developing countries, and high levels of contamination are found in these countries because of this or due to the existence of considerable stocks of uncontrolled obsolete pesticides, which makes it possible for the people and wildlife living there and in the neighboring areas to be under inadvertent exposure (Gioia et al., 2013; Najera et al., 2011; Nweke and Sanders, 2009). The fact that DDT is currently used as an insecticide in Morocco, which is only $100 \mathrm{~km}$ away from the Canary Islands archipelago, supports this hypothesis.

\subsection{Accumulation pattern of PCBs}

We detected residues of PCBs in all the samples that were analyzed within a range of 2 to 15 different congeners (Table 2). Only PCB 169

Table 1

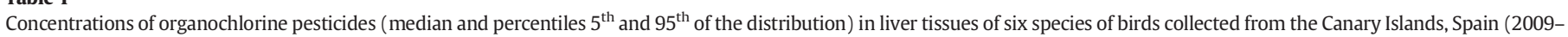
2012). Results are expressed in ng/g wet mass and in $\mathrm{ng} / \mathrm{g}$ lipid weight [between brackets].

\begin{tabular}{|c|c|c|c|c|c|c|}
\hline Bird species & $\sum \mathrm{DDT}$ & Dieldrin & $\sum \mathrm{HCH}$ & $\mathrm{HCB}$ & Dicofol & $\sum \mathrm{OCP}$ \\
\hline \multirow[t]{2}{*}{ Accipiter nisus } & $1955.8[41,785.6]$ & 88.5 [1890.4] & $190.2[4058.4]$ & $2.7[57.3]$ & $1.0[21.4]$ & $2160.4[46,146.2]$ \\
\hline & $(141.6-24772.3)$ & $(47.1-1423.9)$ & $(28.8-426.8)$ & (n.d.-634.1) & (n.d.-3.53) & $(383.5-25,249.8)$ \\
\hline \multirow[t]{2}{*}{ Asio otus } & $475.8[10,727.4]$ & 189.7 [4276.9] & $141.8[3199.0]$ & $0.4[9.1]$ & $2.7[60.4]$ & $770.6[17,369.3]$ \\
\hline & $(60.1-7838.9)$ & $(112.3-465.4)$ & $(42.6-258.0)$ & (n.d.-5.63) & (n.d.-24.83) & $(249.2-8223.3)$ \\
\hline \multirow[t]{2}{*}{ Buteo buteo } & $403.9[8120.4]$ & $106.5[2141.2]$ & 135.4 [2729.7] & $0.1[2.4]$ & 9.3 [187.5] & 467.1 [9416.7] \\
\hline & $(121.6-2642.4)$ & $(72.1-123.3)$ & $(43.4-597.4)$ & $(0.08-0.22)$ & $(3.9-11.7)$ & $(328.1-2949.4)$ \\
\hline \multirow[t]{2}{*}{ Falco pelegrinoides } & $974.07[18,044.6]$ & $78.4[1452.4]$ & 207.6 [3886.3] & $0.3[5.2]$ & $6.9[129.6]$ & $1419.2[26,567.4]$ \\
\hline & $(70.6-23,064.2)$ & $(18.1-471.4)$ & $(59.8-1049.8)$ & $(0.03-209.3)$ & $(0.4-24.4)$ & $(184.7-24,418.9)$ \\
\hline \multirow[t]{2}{*}{ Falco tinnunculus } & $699.6[14,247.4]$ & $217.3[4425.3]$ & 210.1 [4278.7] & $1.2[24.0]$ & $4.2[85.4]$ & $1154.7[23,475.1]$ \\
\hline & $(35.6-9213.8)$ & $(66.8-570.3)$ & $(15.4-1227.8)$ & $(0.2-3.7)$ & (n.d.-12.5) & $(692.9-10,036.6)$ \\
\hline \multirow[t]{2}{*}{ Tyto alba } & $597.9[12,705.4]$ & $180.3[3831.4]$ & $72.4[1538.5]$ & $0.01[0.2]$ & $2.9[62.7]$ & $848.2[18,024.3]$ \\
\hline & $(30.7-9575.9)$ & $(21.4-402.5)$ & $(14.0-747.7)$ & (n.d.-0.6) & (n.d.-13.2) & $(183.7-9731.1)$ \\
\hline
\end{tabular}

n.d., non-detected.

$\mathrm{HCB}$, hexachlorobenzene.

$\sum$ DDT, sum of $p, p^{\prime}-\mathrm{DDE}, p, p^{\prime}-\mathrm{DDD}+\mathrm{o}, p^{\prime}-\mathrm{DDT}, p, p^{\prime}-\mathrm{DDT}, \mathrm{o}, p^{\prime}-\mathrm{DDE}, \mathrm{o}, p^{\prime}-\mathrm{DDD}$

$\sum$ OCs: sum of all analyzed OCs. 
Table 2

Concentrations of polychlorinated biphenyls (median and percentiles $5^{\text {th }}$ and $95^{\text {th }}$ of the distribution) in liver tissues of six species of birds collected from the Canary Islands, Spain (2009-2012). Results are expressed in ng/g wet mass and in ng/g lipid weight [between brackets].

\begin{tabular}{lllll}
\hline Bird species & $\sum$ M-PCBs & $\sum$ DL-PCBs & $\sum$ TEQ $_{\mathrm{DL}-\mathrm{PCB}}{ }^{\mathrm{a}}$ & $\sum \mathrm{PCBs}$ \\
\hline Accipiter nisus & $33.1[707.0]$ & $4.4[94.0]$ & $0.2[4.3]$ & $35.6[760.4]$ \\
& $(0.3-2906.5)$ & $(0.1-449.5)$ & $(0.1-13.48)$ & $(0.3-3090.9)$ \\
Asio otus & $0.8[18.1]$ & $0.2[4.5]$ & $0.05[1.1]$ & $0.9[20.3]$ \\
& $(0.1-86.4)$ & $(0.1-10.8)$ & $(0.0-0.3)$ & $(0.1-92.81)$ \\
Buteo buteo & $0.7[14.7]$ & $0.2[4.0]$ & $0.1[2.0]$ & $0.8[16.1]$ \\
& $(0.2-0.5)$ & $(0.1-0.3)$ & $(0.1-0.4)$ & $(0.3-0.7)$ \\
Falco pelegrinoides & $28.8[533.4]$ & $6.1[57.4]$ & $0.2[3.7]$ & $32.3[598.2]$ \\
& $(8.5-4032.5)$ & $(2.2-1507.3)$ & $(0.1-46.1)$ & $(9.5-10.645 .8)$ \\
Falco tinnunculus & $16.4[333.9]$ & $1.7[34.6]$ & $0.1[2.0]$ & $16.8[342.1]$ \\
& $(3.9-89.7)$ & $(0.4-7.9)$ & $(0.0-0.3)$ & $(4.2-95.8)$ \\
Tyto alba & $0.4[8.5]$ & $0.1[2.1]$ & $0.1[2.1]$ & $0.6[12.8]$ \\
& $(0.1-4.8)$ & $(0.1-0.9)$ & $(0.0-0.4)$ & $(0.1-5.5)$
\end{tabular}

$\sum$ M-PCBs, sum of marker PCBs (congeners 28, 52, 101, 118, 138, 153, and 180).

$\sum$ DL-PCBs, sum of dioxin-like PCBs (congeners 77, 81, 105, 114, 118, 123, 126, 156, 157 , 167,169 and 189).

$\sum$ PCBs, sum of all measured PCBs (congeners, 28, 52, 77, 81, 101, 105, 114, 118, 123, 126 , $138,153,156,157,167,169,180$, and 189).

a Expressed in $\mathrm{pg} / \mathrm{g}$ wet weight.

was not detected in any sample. However, in our set of samples, PCB numbers $28,118,138,153$ and 180 were the most prevalent congeners, with PCB numbers 28,118 and 153 detected in $100 \%$ of samples $(3.8,2.7$ and $3.4 \mathrm{ng} / \mathrm{g}$, respectively) and with PCB numbers 138 and 180 detected in $97.1 \%$ of the samples ( 1.4 and $2.1 \mathrm{ng} / \mathrm{g}$, respectively). More than $95 \%$ of the content of PCBs came from M-PCBs. This result is consistent with studies that have found PCBs 180 and 153 as the most predominant congeners (Gomez-Ramirez et al., 2012) and with other studies that have also found high levels of contamination by PCB 28 (Wan et al., 2011).

Regarding PCB contamination in this region, previous studies by our group in humans and in food items have revealed that the level was relatively low (Almeida-Gonzalez et al., 2012; Henriquez-Hernandez et al., 2011; Luzardo et al., 2012), which was expected as the Canary Islands are a relatively non-industrialized area. We expected to find also very low levels of PCBs in these samples of birds living in the same region, but as shown in Table 2, the levels found were not so low as it would be expected. However, the levels of contamination by POPs can be enormously different among populations depending on the geographical region in which they live, and the local environment greatly influences the levels of contaminants that are found (El-Shahawi et al., 2010). However, it seems obvious that there are other unknown factors that influence the PCB levels in these birds. Nevertheless, the levels in our series are much lower than those levels that were found in raptors from other regions: USA (range from 1.34 to $10,500.0 \mathrm{ng} / \mathrm{g}$ wet weight) (Yordy et al., 2013), Belgium (range from 285.0 to $8690.0 \mathrm{ng} / \mathrm{g}$ wet weight) (Jaspers et al., 2008), Italy (range from 131.0 to $3050.0 \mathrm{ng} / \mathrm{g}$ wet weight) (Licata et al., 2012), Greenland (median 11,000 ng/g lipid weight) (Jaspers et al., 2013), Southern Spain (median $544.7 \mathrm{ng} / \mathrm{g}$ lipid weight) (Gomez-Ramirez et al., 2012) and it may be possible that these animals were not at toxicological risk for PCBs.

As in the case of OCPs, we observed significant differences in the levels that were found among species (Fig. 2), and again we found that A. nisus, F. pelegrinoides, and F. tinnunculus were, in that order, the species that displayed the highest levels of $\sum$ PCBs (Fig. 2). Variations in the diet as well as the species-specific accumulation and metabolism of PCBs may be the most important causes that explain these differences, as it has been described for other species including human beings (Beyer and Biziuk, 2009; D'Ilio et al., 2011; Gasull et al., 2011). Differences among species have also been found by other authors (Jaspers et al., 2008); however, the pattern of raptors from the Canaries is completely different from other regions. Thus, in the study by Jaspers et al. (2006), T. Alba and A. nisus were the most contaminated of the analyzed species, with 150,000 and $140,000 \mathrm{ng} / \mathrm{g}$ of $\sum \mathrm{PCBs}$, respectively.
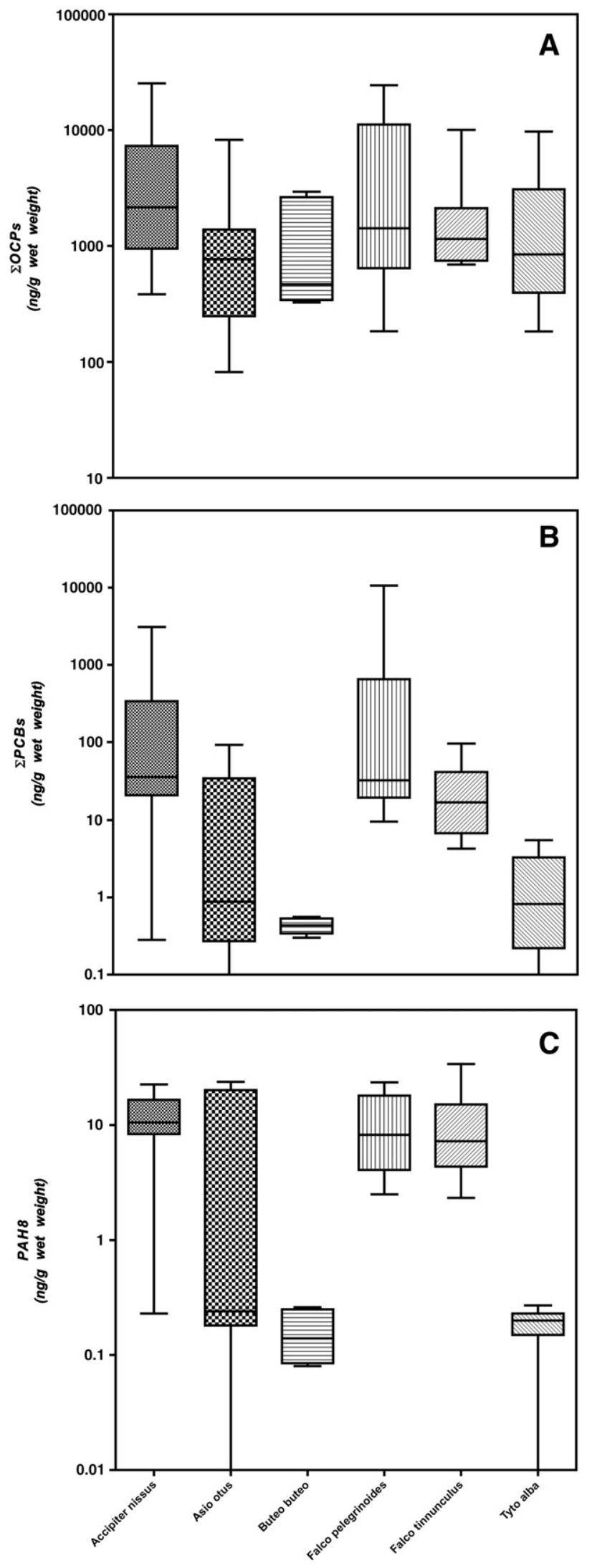

Fig. 2. Box plot indicating the levels of $\sum$ OCs (panel A), $\sum$ PCBs (panel B), and $\sum$ PAH8 (panel C) in the six species that were included in the study. The line inside the box represents the median, the bottom and top of the box are the first and third quartiles of the distribution, and the lines extending vertically from the boxes indicate the variability outside the upper and lower quartiles. 
In our study, the levels found in both species were much lower, and T. alba was the species that displayed the lowest levels $(0.8 \mathrm{ng} / \mathrm{g}$ wet weight, Table 2). To our knowledge, this report is the first that tests the levels of contamination by PCBs in Barbary Falcons (F.pelegrinoides).

\subsection{Accumulation pattern of PAHs}

Of the 16 PAH compounds that were analyzed, 15 were detected in one or more of the six species that were analyzed. Only dibenzo[a,h]anthracene was not detected in any of the samples, and thus, the remaining 15 compounds were considered for $\sum$ PAHs. Additionally, 3 compounds were detected in $100 \%$ of the samples: phenanthrene, fluoranthene, and pyrene, consistent with other authors who showed that phenanthrene is the most frequent $\mathrm{PAH}$ in samples from predatory birds in Britain (Pereira et al., 2009). Regarding concentrations, naphthalene was the compound that reached the highest values by far (median $1152 \mathrm{ng} / \mathrm{g}$, range 2.2 to $63,240.8 \mathrm{ng} / \mathrm{g}$ wet weight).

As in the case of organochlorine compounds, we found great differences in the total content of PAHs among both different species and individual samples from each species (Fig. 2). Thus, the median $\sum \mathrm{PAH}$ concentration among the six species ranged from 48.9 to $53995.3 \mathrm{ng} / \mathrm{g}$ wet weight; however, the individual values ranged from 9.2 to $80053.2 \mathrm{ng} / \mathrm{g}$ wet weight (Table 3). Notably, the species that showed less contamination by $\sum$ PAHs were those species whose diet was primarily composed of birds ( $F$. pelegrinoides $<F$. tinnunculus $<A$. nisus), whereas the other three species, which feed mainly on small mammals and reptiles were those species that showed the highest levels of the sum of these contaminants (Table 3 ). The extremely high values of $\sum$ PAHs that we have found in some species and individuals are primarily due to the high content of low molecular weight PAHs, particularly naphthalene, which contributed more than $99 \%$ of $\sum$ PAHs in the most contaminated species (Fig. 3B). Therefore, it seems a plausible hypothesis that there could exist a source of naphthalene that is probably related to the similar feeding patterns of these three species. However, we do not have data on feedstuff to support this hypothesis, and further research is needed to elucidate this issue. When we separate the PAHs according to their molecular weights, and we consider only the sum of the more weighted ones (mainly to exclude the less toxic, but highly abundant, naphthalene), the differences among species become less evident (range from 10.5 to $35.5 \mathrm{ng} / \mathrm{g}$ wet weight), and the pattern of contamination among species varies. This pattern is paradoxical because the less contaminated species are precisely those species that feed on mammals and reptiles. This pattern is maintained when we consider only those PAHs for which oral carcinogenicity data were available ( $\sum$ PAH8: benzo[a]pyrene, benz[a]anthracene, benzo[b]fluoranthene, benzo[k] fluoranthene, benzo[ghi]perylene, chrysene, dibenz[a,h]anthracene and indeno[1,2,3-cd]pyrene), as well as when we used the classical toxic equivalency factor (TEF) approach to the risk characterization of the PAH mixtures, and expressed these mixtures as benzo[a]pyrene toxic equivalents $\left(\mathrm{TEQ}_{\mathrm{B}[\mathrm{a}] \mathrm{p}}\right.$, Table 3$)$. As other authors have described in other environmental samples, the contribution of $\mathrm{TEQ}_{\mathrm{B}[\mathrm{a}] \mathrm{p}}$ to the total dioxinlike activity was much higher (>1000 times) than that of TEQ $\mathrm{DL}_{\mathrm{DCBs}}$ (Eljarrat et al., 2001). In any case, according to the concentrations of carcinogenic PAHs that were detected in the liver tissues of the birds that were included in the present study, the risk of acute toxic effects to these birds can be considered moderate when compared with the model for predicting the toxicity of polycyclic aromatic hydrocarbon mixtures (Reeves et al., 2001).

These values of our study (without including naphthalene) can be compared with those values that were found by other authors in the liver of birds from other regions of the world. Thus, the levels in our study are lower than those levels that were found in birds from India, Australia, USA and Britain (overall range from 79 to $382 \mathrm{ng} / \mathrm{g}$ wet weight) (Custer et al., 2000; Dhananjayan, 2013a; Kayal and Connel, 1995; Shore et al., 1999). It seems logical that our levels were much lower than those levels that were found in oiled seabirds from the North Atlantic (mean 245 ng/g wet weight) (Troisi et al., 2006) but higher than those levels found in seabirds from the Canaries and the Mediterranean Sea (mean $13.1 \pm 11.7 \mathrm{ng} / \mathrm{g}$ wet weight) (Roscales et al., 2011). Notably, the studies that report the levels of these contaminants in the liver of predatory birds, or even in terrestrial birds, are scarce in the literature. Thus, these comparisons should be taken with caution because they have been made with the data that were obtained from species that live in a different environment and that have a completely different feeding pattern. To our knowledge, this report is the first of PAHs levels in tissues of all of the six species that were included in the present study, and it is expected that the data that were generated in this study will serve as reference values for future studies.

Taken together, we observed that the total load of contaminants greatly varies depending on the species and that the total load of contaminants can also be extremely different among individuals of the same species (Fig. 2). However, the profile of contaminants (the percentage of each pollutant or group of pollutants) is particularly similar in the case of organochlorines. Thus, the total load of $\sum$ DDTs invariably accounted for more than $60 \%$ of total organochlorines (Fig. 3A). Dieldrin and the sum of $\mathrm{HCH}$ isomers were also major contributors to the total load of organochlorine contaminants. However, as suggested above, the profile of contamination by PAHs seems to be related to the feeding pattern of the species. Thus, this profile is particularly similar among the bird-eating raptor species but is different from the profile of those species that feed on small mammals and reptiles (Fig. 3B).

Table 3

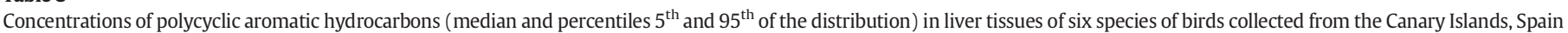
(2009-2012). Results are expressed in ng/g wet mass and in ng/g lipid weight [between brackets].

\begin{tabular}{|c|c|c|c|c|c|}
\hline Bird species & $\sum \mathrm{PAHs}_{\mathrm{lw}}$ & $\sum \mathrm{PAHs}_{\mathrm{hw}}$ & $\sum$ РAH8 & $\mathrm{TEQ}_{\mathrm{BaP}}$ & $\sum$ PAHs \\
\hline Accipiter nisus & $\begin{array}{l}380.9[8136.0] \\
(49.5-2216.6)\end{array}$ & $\begin{array}{l}35.5[758.28] \\
(0.9-82.7)\end{array}$ & $\begin{array}{l}10.5[224.3] \\
(0.2-22.6)\end{array}$ & $\begin{array}{l}5.4[115.3] \\
(0.1-12.4)\end{array}$ & $\begin{array}{l}421.5[9003.2] \\
(90.3-2217.4)\end{array}$ \\
\hline Asio otus & $\begin{array}{l}3966.3[89,400.4] \\
(1267.4-15,412.2)\end{array}$ & $\begin{array}{l}0.6[13.54] \\
(0.0-83.1)\end{array}$ & $\begin{array}{l}0.2[4.5] \\
(0.0-23.7)\end{array}$ & $\begin{array}{l}0.1[2.3] \\
(0.0-17.5)\end{array}$ & $\begin{array}{l}3966.7[89,409.4] \\
(1345.7-15,413.0)\end{array}$ \\
\hline Buteo buteo & $\begin{array}{l}53,994.7[1,085,293.5] \\
(6816.5-80,052.8)\end{array}$ & $\begin{array}{l}0.4[8.0] \\
(0.3-1.0)\end{array}$ & $\begin{array}{l}0.2[4.0] \\
(0.1-0.3)\end{array}$ & $\begin{array}{l}0.1[2.0] \\
(0.0-0.2)\end{array}$ & $\begin{array}{l}53995.3[1,085,305.5] \\
(6816.8-80,053.2)\end{array}$ \\
\hline Falco pelegrinoides & $\begin{array}{l}27.3[505.6] \\
(4.0-270.0)\end{array}$ & $\begin{array}{l}17.4[322.3] \\
(5.2-58.0)\end{array}$ & $\begin{array}{l}8.2[164.8] \\
(2.5-23.5)\end{array}$ & $\begin{array}{l}2.2[40.2] \\
(0.6-5.8)\end{array}$ & $\begin{array}{l}48.9[949.8] \\
(9.2-290.5)\end{array}$ \\
\hline Falco tinnunculus & $\begin{array}{l}543.9[11,073.8] \\
(130.5-4277.0)\end{array}$ & $\begin{array}{l}27.0[549.7] \\
(7.0-114.4)\end{array}$ & $\begin{array}{l}7.2[146.6] \\
(2.3-33.9)\end{array}$ & $\begin{array}{l}4.2[85.5] \\
(1.2-15.6)\end{array}$ & $\begin{array}{l}611.0[12,439.9] \\
(138.2-4356.6)\end{array}$ \\
\hline Tyto alba & $\begin{array}{l}6480.6[137,712.7] \\
(2335.2-31,383.1)\end{array}$ & $\begin{array}{l}0.5[10.7] \\
(0.0-0.6)\end{array}$ & $\begin{array}{l}0.2[4.2] \\
(0.0-0.3)\end{array}$ & $\begin{array}{l}0.1[2.1] \\
(0.0-0.2)\end{array}$ & $\begin{array}{l}6481.1[137,723.4] \\
(2335.7-31,383.5)\end{array}$ \\
\hline
\end{tabular}

$\sum$ di-, tri- cyclic PAHs (low molecular weight PAHs): sum of naphthalene, acenaphthylene, acenaphthene, fluorene, phenanthrene, and anthracene.

$\sum$ tetra-, penta-, hexa cyclic PAHs (high molecular weight PAHs): sum of fluoranthene, pyrene, chrysene, benz[a]anthracene, benzo[b]fluoranthene, benzo[k]fluoranthene,

Benzo[a]pyrene, indeno[1,2,3-c,d]pyrene, benzo[g,h,i]perylene, and benzo[a,h]anthracene.

$\sum$ PAHs, sum of all compounds. 


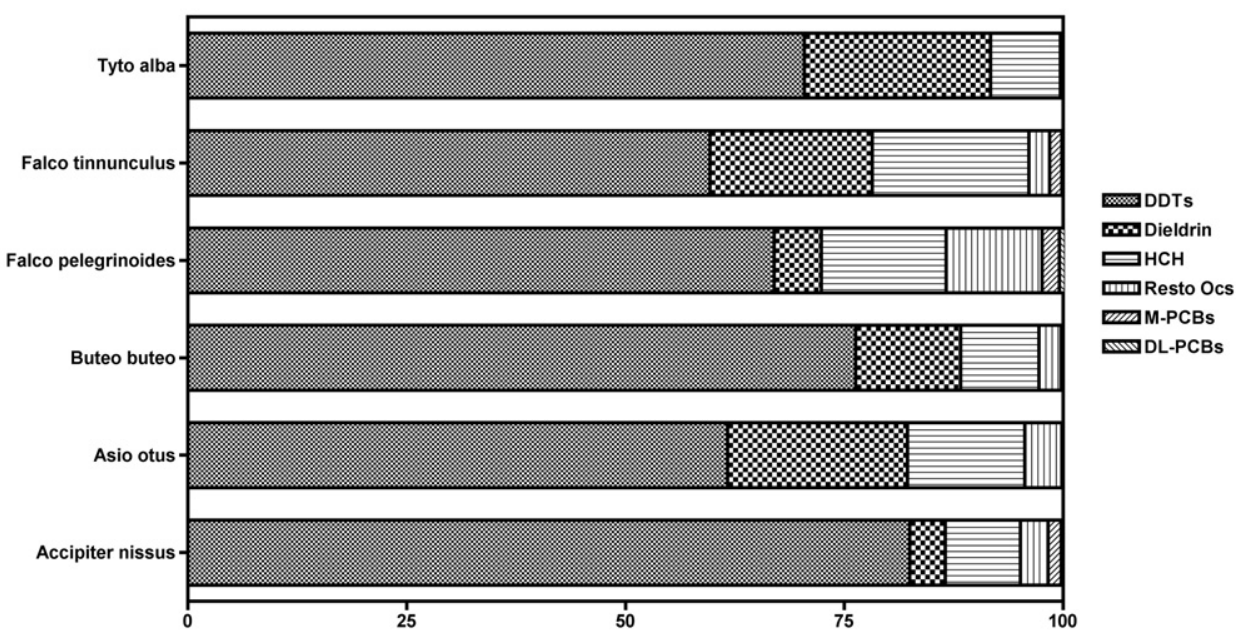

B

Polycyclic Aromatic Hydrocarbons

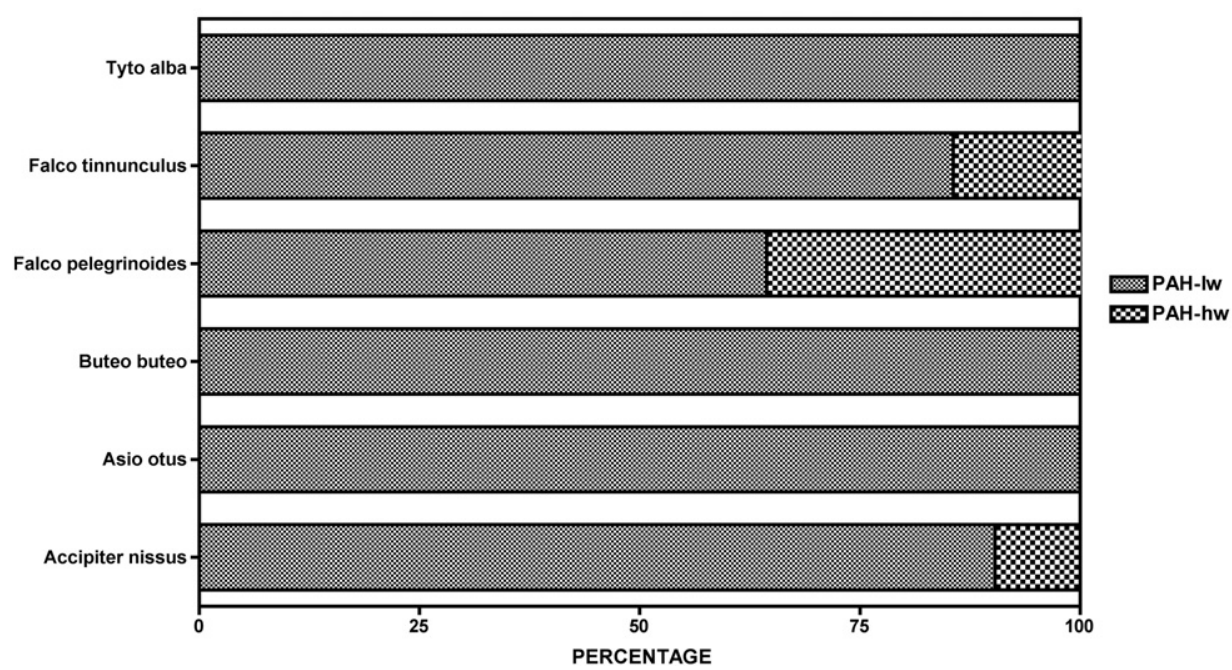

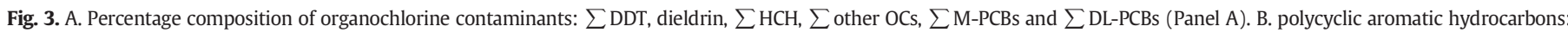
$\sum \mathrm{PAH}$ of low molecular weight and $\sum \mathrm{PAH}$ of high molecular weight in the six species of birds of prey that were collected from the Canary Islands, Spain.

\section{Conclusions}

The levels of 57 POPs were determined in 102 birds belonging to six different species from the Canary Islands (Spain). We observed significant differences in the content of contaminants among species, although the variability of individuals within each species was high. The profiles of contamination among species were extremely similar in the case of organochlorine contaminants, including DDT, dieldrin, and $\mathrm{HCH}$ isomers as the most abundant compounds. The contamination by DDT and its metabolites, as well as contamination by dieldrin, can be considered high in these animals, with much higher levels than reports from other regions of the world, which is in agreement with previous reports from our group regarding humans, food and other animals from this area. The high levels of organochlorine pesticides, especially DDTs and dieldrin, add more evidence to the previously reported high level of contamination by these compounds in the Canary Islands. In contrast, the contamination by PCBs can be considered low, with M-PCBs contributing the most to the total load of these contaminants. These PCB levels are not considered a toxic risk for these animals. These results are also in consonance with previous reports of environmental and human samples from the same area. The same consideration can be made for the PAH content in these species because the levels are well below the values that are considered toxic in predictive models. The PAH content of these animals seems to be somewhat dependent on the feeding pattern of the species, with the content of low-molecular-weight compounds much higher in those animals that feed on small mammals and reptiles than in the raptors that feed on other birds. However, further research is needed to elucidate this topic. This study represents the first report of contamination by PAHs in all these species. Taken together, the results of this study indicate that the level of contamination of these birds is moderate to low for PCBs and PAHs and high for OCPs, being in consonance with previous reports from samples in the same area. This indicates that carcasses of birds of prey of the archipelago may be used as an additional indicator to assess the level of contamination of this area.

\section{Conflict of interest}

The authors declare no conflict of interest.

\section{Acknowledgments}

The authors would like to thank the veterinarians of the Wildlife Recovery Centers of Gran Canaria (Pascual Calabuig and Dolores Estévez) 
and Tenerife (Santiago Mayans) for their collaboration in the necropsies and in the sampling of the animals. We would also like to thank Mrs. María de los Reyes Suárez Hanna for her technical assistance.

\section{References}

Addison RF, Muir DC, Ikonomou MG, Harwood L, Smith TG, Alikamik J. Temporal trends in "legacy" organochlorine contaminants in blubber of ringed seals (Phoca hispida) from Ulukhaktok, NT, Canada between 1972 and 2010. Sci Total Environ 2013:564-76. [466-467C].

Almeida-Gonzalez M, Luzardo OP, Zumbado M, Rodriguez-Hernandez A, Ruiz-Suarez N, Sangil $\mathrm{M}$, et al. Levels of organochlorine contaminants in organic and conventional cheeses and their impact on the health of consumers: an independent study in the Canary Islands (Spain). Food Chem Toxicol 2012;50:4325-32.

Beyer A, Biziuk M. Environmental fate and global distribution of polychlorinated biphenyls. Rev Environ Contam Toxicol 2009;201:137-58.

Bourgeon S, Leat EK, Furness RW, Borga K, Hanssen SA, Bustnes JO. Dietary versus maternal sources of organochlorines in top predator seabird chicks: an experimental approach. Environ Sci Technol 2013;47:5963-70.

Camacho M, Boada LD, Oros J, Calabuig P, Zumbado M, Luzardo OP. Comparative study of polycyclic aromatic hydrocarbons (PAHs) in plasma of Eastern Atlantic juvenile and adult nesting loggerhead sea turtles (Caretta caretta). Mar Pollut Bull 2012;64 1974-80.

Camacho M, Luzardo OP, Boada LD, Lopez Jurado LF, Medina M, Zumbado M, et al. Potential adverse health effects of persistent organic pollutants on sea turtles: evidences from a cross-sectional study on Cape Verde loggerhead sea turtles. Sci Total Environ 2013:283-9. [458-460C].

Custer TW, Custer CM, Hines RK, Sparks DW. Trace elements, organochlorines, polycyclic aromatic hydrocarbons, dioxins, and furans in lesser scaup wintering on the Indiana Harbor Canal. Environ Pollut 2000;110:469-82.

Dhananjayan V. Accumulation pattern and distribution of polycyclic aromatic hydrocarbons (PAHs) in liver tissues of seven species of birds from Ahmedabad, India, during 2005-2007. Environ Sci Pollut Res Int 2013a;20:3414-22.

Dhananjayan V. Accumulation pattern of persistent organochlorine pesticides in liver tissues of various species of birds from India. Environ Sci Pollut Res Int 2013b;20: 3149-56.

Diaz-Diaz R, Loague K. Assessing the potential for pesticide leaching for the pine forest areas of Tenerife. Environ Toxicol Chem 2001;20:1958-67.

D'Ilio S, Mattei D, Blasi MF, Alimonti A, Bogialli S. The occurrence of chemical elements and POPs in loggerhead turtles (Caretta caretta): an overview. Mar Pollut Bull 2011;62:1606-15

Eljarrat E, Caixach J, Rivera J, de Torres M, Ginebreda A. Toxic potency assessment of nonand mono-ortho PCBs, PCDDs, PCDFs, and PAHs in northwest Mediterranean sediments (Catalonia, Spain). Environ Sci Technol 2001;35:3589-94.

El-Shahawi MS, Hamza A, Bashammakh AS, Al-Saggaf WT. An overview on the accumulation, distribution, transformations, toxicity and analytical methods for the monitoring of persistent organic pollutants. Talanta 2010;80:1587-97.

EN European Norm 1528-2. Fatty food - determination of pesticides and polychlorinated biphenyls (PCBs) - part 2: extraction of fat, pesticides and PCBs, and determination of fat content. European Committee for Standardization; 1996.

EN European Norm 1528-3. Fatty food. Determination of pesticides and polychlorinated biphenyls (PCBs). Clean-up methods. European Committee for Standardization: 1996.

Fernie KJ, Letcher RJ. Historical contaminants, flame retardants, and halogenated phenolic compounds in peregrine Falcon (Falco peregrinus) nestlings in the Canadian Great Lakes Basin. Environ Sci Technol 2010;44:3520-6.

Gasull M, Bosch de Basea M, Puigdomenech E, Pumarega J, Porta M. Empirical analyses of the influence of diet on human concentrations of persistent organic pollutants: a systematic review of all studies conducted in Spain. Environ Int 2011;37:1226-35.

Gioia R, Akindele AJ, Adebusoye SA, Asante KA, Tanabe S, Buekens A, et al. Polychlorinated biphenyls (PCBs) in Africa: a review of environmental levels. Environ Sci Pollut Res Int 2013. http://dx.doi.org/10.1007/s11356-013-1739-1. (Electronic publication ahead of print).

Gomez-Ramirez P, Martinez-Lopez E, Garcia-Fernandez AJ, Zweers AJ, van den Brink NW. Organohalogen exposure in a Eurasian Eagle owl (Bubo bubo) population from South eastern Spain: temporal-spatial trends and risk assessment. Chemosphere 2012;88: 903-11.

Hamlin HJ, Guillette Jr LJ. Birth defects in wildlife: the role of environmental contaminants as inducers of reproductive and developmental dysfunction. Syst Biol Reprod Med 2010;56:113-21.

Henriquez-Hernandez LA, Luzardo OP, Almeida-Gonzalez M, Alvarez-Leon EE, SerraMajem L, Zumbado M, et al. Background levels of polychlorinated biphenyls in the population of the Canary Islands (Spain). Environ Res 2011;111:10-6.

Iwaniuk AN, Koperski DT, Cheng KM, Elliott JE, Smith LK, Wilson LK, et al. The effects of environmental exposure to DDT on the brain of a songbird: changes in structures associated with mating and song. Behav Brain Res 2006;173:1-10.

Jaspers VL, Covaci A, Voorspoels S, Dauwe T, Eens M, Schepens P. Brominated flame retardants and organochlorine pollutants in aquatic and terrestrial predatory birds of Belgium: levels, patterns, tissue distribution and condition factors. Environ Pollut 2006;139:340-52.

Jaspers VL, Dirtu AC, Eens M, Neels H, Covaci A. Predatory bird species show different patterns of hydroxylated polychlorinated biphenyls (HO-PCBs) and polychlorinated biphenyls (PCBs). Environ Sci Technol 2008;42:3465-71.

Jaspers VL, Sonne C, Soler-Rodriguez F, Boertmann D, Dietz R, Eens M, et al. Persisten organic pollutants and methoxylated polybrominated diphenyl ethers in different tissues of white-tailed eagles (Haliaeetus albicilla) from West Greenland. Environ Pollut 2013:175:137-46.

Kayal S, Connel DW. Polycyclic aromatic hydrocarbons in biota from the Brisbane River Estuary, Australia. Estuar Coast Shelf Sci 1995;40:475-93.

Licata P, Naccari F, Dugo G, Fotia V, Lo Turco V, Potorti AG, et al. Organochlorine pesticides and polychlorinated biphenyls in common buzzard (Buteo buteo) from Sicily (Italy). Environ Monit Assess 2012;184:2881-92.

Lorenzo JA, Alonso-Alonso JR, Barone-Tosco R, González-González C. Atlas de las aves nidificantes en el archipiélago canario. Tenerife. Islas Canarias. España: Ministerio de Medioambiente. Gobierno de España; 2012.

Luzardo OP, Goethals M, Zumbado M, Alvarez-Leon EE, Cabrera F, Serra-Majem L, et al. Increasing serum levels of non-DDT-derivative organochlorine pesticides in the younger population of the Canary Islands (Spain). Sci Total Environ 2006;367:129-38.

Luzardo OP, Mahtani V, Troyano JM, Alvarez de la Rosa M, Padilla-Perez AI, Zumbado M, et al. Determinants of organochlorine levels detectable in the amniotic fluid of women from Tenerife Island (Canary Islands, Spain). Environ Res 2009;109:607-13.

Luzardo OP, Almeida-Gonzalez M, Henriquez-Hernandez LA, Zumbado M, Alvarez-Leon EE, Boada LD. Polychlorobiphenyls and organochlorine pesticides in conventional and organic brands of milk: occurrence and dietary intake in the population of the Canary Islands (Spain). Chemosphere 2012;88:307-15

Luzardo OP, Rodriguez-Hernandez A, Quesada-Tacoronte Y, Ruiz-Suarez N, AlmeidaGonzalez M, Henriquez-Hernandez LA, et al. Influence of the method of production of eggs on the daily intake of polycyclic aromatic hydrocarbons and organochlorine contaminants: an independent study in the Canary Islands (Spain). Food Chem Toxicol 2013a;60:455-62.

Luzardo OP, Rodriguez-Hernandez A, Quesada-Tacoronte Y, Ruiz-Suarez N, AlmeidaGonzalez M, Henriquez-Hernandez LA, et al. Influence of the method of production of eggs on the daily intake of polycyclic aromatic hydrocarbons and organochlorine contaminants: an independent study in the Canary Islands (Spain). Food Chem Toxicol 2013b;60:455-62.

Luzardo OP, Ruiz-Suarez N, Almeida-Gonzalez M, Henriquez-Hernandez LA, Zumbado M, Boada LD. Multi-residue method for the determination of 57 Persistent Organic Pollutants in human milk and colostrum using a QuEChERS-based extraction procedure. Anal Bioanal Chem 2013c;405:9523-36.

MAGRAMA. Perfil Ambiental de España 2006, Informe basado en indicadoresIn: Ministerio de Agricultura AyMAGdE, editor. ; 2006.

MAGRAMA. Memoria 2011 - Red de Parques Nacionales. Ministerio de Agricultura, Alimentación y Medio Ambiente. Gobierno de España; 2013.

Malik RN, Rauf S, Mohammad A, Eqani SA, Ahad K. Organochlorine residual concentrations in cattle egret from the Punjab Province, Pakistan. Environ Monit Assess 2011;173:325-41.

Najera JA, Gonzalez-Silva M, Alonso PL. Some lessons for the future from the Global Malaria Eradication Programme (1955-1969). PLoS Med 2011;8:e1000412.

Nweke OC, Sanders 3rd WH. Modern environmental health hazards: a public health issue of increasing significance in Africa. Environ Health Perspect 2009;117:863-70.

Olafsdottir K, Petersen AE, Magnusdottir EV, Bjornsson T, Johannesson T. Persistent organochlorine levels in six prey species of the gyrfalcon Falco rusticolus in Iceland. Environ Pollut 2001;112:245-51.

Pereira MG, Walker LA, Wright J, Best J, Shore RF. Concentrations of polycyclic aromatic hydrocarbons (PAHs) in the eggs of predatory birds in Britain. Environ Sci Technol 2009;43:9010-5.

Ratcliffe DA. Decrease in eggshell weight in certain birds of prey. Nature 1967;215: 208-10.

Reeves WR, Barhoumi R, Burghardt RC, Lemke SL, Mayura K, McDonald TJ, et al. Evaluation of methods for predicting the toxicity of polycyclic aromatic hydrocarbon mixtures. Environ Sci Technol 2001;35:1630-6.

Roscales JL, Gonzalez-Solis J, Calabuig P. Jimenez B. Interspecies and spatial trends in polycyclic aromatic hydrocarbons (PAHs) in Atlantic and Mediterranean pelagic seabirds. Environ Pollut 2011;159:2899-905

Ryan MJ, Stern GA, Kidd KA, Croft MV, Gewurtz S, Diamond M, et al. Biotic interactions in temporal trends (1992-2010) of organochlorine contaminants in the aquatic food web of Lake Laberge, Yukon Territory. Sci Total Environ 2013;443:80-92.

Safe SH. Polychlorinated biphenyls (PCBs): environmental impact, biochemical and toxic responses, and implications for risk assessment. Crit Rev Toxicol 1994;24: 87-149.

Schuster JK, Gioia R, Moeckel C, Agarwal T, Bucheli TD, Breivik K, et al. Has the burden and distribution of PCBs and PBDEs changed in European background soils between 1998 and 2008? Implications for sources and processes. Environ Sci Technol 2011;45: 7291-7.

Shore RF, Wright J, Horne JA, Sparks TH. Polycyclic aromatic hydrocarbon (PAH) residues in the eggs of coastal-nesting birds from Britain. Mar Pollut Bull 1999;38:509-13.

Tillitt DE, Ankley GT, Giesy JP, Ludwig JP, Kurita-Matsuba H, Weseloh DV, et al. Polychlorinated biphenyl residues and egg mortality in double-crested cormorants from the great lakes. Environ Toxicol Chem 1992;11:1281-8.

Troisi GM, Bexton S, Robinson I. Polyaromatic hydrocarbon and PAH metabolite burdens in oiled common guillemots (Uria aalge) stranded on the east coast of England (2001-2002). Environ Sci Technol 2006;40:7938-43.

Wan X, Pan X, Wang B, Zhao S, Hu P, Li F, et al. Distributions, historical trends, and source investigation of polychlorinated biphenyls in Dianchi Lake, China. Chemosphere 2011;85:361-7.

Yordy JE, Rossman S, Ostrom PH, Reiner JL, Bargnesi K, Hughes S, et al. Levels of chlorinated, brominated, and perfluorinated contaminants in birds of prey spanning multiple trophic levels. J Wildl Dis 2013;49:347-54.

Zumbado M, Goethals M, Alvarez-Leon EE, Luzardo OP, Cabrera F, Serra-Majem L, et al. Inadvertent exposure to organochlorine pesticides DDT and derivatives in people from the Canary Islands (Spain). Sci Total Environ 2005;339:49-62. 